Acta vet. scand. $1964,5,257-264$.

From the Department of Reproductive Physiology and Pathology, Veterinary College of Norway, Oslo.

\title{
BOVINE COLOSTRUM LEVELS OF OESTRONE AND OESTRADIOLS
}

By

\author{
Torleiv Lunaas
}

The oestrogenic activity of bovine colostrum has previously been assayed with the mouse uterine weight method. In colostrum from which fat had been removed in a cream separator, Pope and Roy (1953) obtained an oestrogenic activity equivalent to about $5 \mu \mathrm{g}$ oestradiol-17 $\beta$ per 1 . The oestrogenic activity in "clarified fat" equaled less than $0.2 \mu \mathrm{g}$ per 1 of colostrum. Most of the oestrogenic activity demonstrated was apparently due to substances being present in the colostrum as water soluble conjugates which could be cleaved by treatment with hot acid. The potency of the postulated conjugates of the oestrogenic substances was not examined. With the methods applied, which included parenteral administration of the final extracts to the test animals, no significant oestrogenic activity was obtained in normal milk. Turner (1958) compared the oestrogenic activity in colostrum and milk by feeding dried, otherwise intact, samples to the test animals. The results indicated that the contents of oestrogenic substances in colostrum were very low and not much different from those in milk obtained during the first three months of the lactation period. The results of the two investigations cited are compatible if it is assumed that in the mouse the oestrogenic potency of the conjugated colostrum oestrogens, when received orally, is low in comparison with that of the free oestrogens administered parenterally.

As far as the author is aware, the chemical nature of the oestrogens in bovine colostrum has not been reported. In this paper the results are presented of an attempt to determine the 
colostrum levels of oestrone, oestradiol-17 $\beta$ and oestradiol-17 $\alpha$. These oestrogens are the major ones present in the bovine placenta (Veenhuizen, Erb \& Gorski 1960) which is presumably the production site of the large amounts of oestrogens being excreted during the later stages of the gestation and at term, when lactation is initiated.

\section{MATERIAL AND METHODS}

Samples of colostrum from the 1st, 2nd and 3rd drawings were obtained from cows with uneventful parturition. The specimens were stored at $-20^{\circ} \mathrm{C}$ until processed for analysis.

The method applied was essentially the same as that previously developed for the analysis of oestrogens in milk collected prior and to after parenteral administration of oestradiol-17 $\beta$ (Lunaas 1963). This procedure was based on the chromatographic method of Brown (1955) and included colour development acording to Ittrich (1958) with extraction of the Kober colour into methylene chloride containing p-nitrophenol for spectrofluorimetry (Lunaas 1962). All determinations were carried out by duplicate analysis of $25 \mathrm{ml}$ colostrum diluted with $25 \mathrm{ml}$ of water. In the initial step introduced i.a. to remove fat, the light petroleum ether was replaced by toluene which was added to the alkaline ethanol - colostrum mixture prior to refluxing on the water bath. Ether insoluble material was refluxed for 15 minutes in $100 \mathrm{ml}$ of water with $3 \mathrm{ml}$ of hydrochloric acid for the hydrolysis of conjugates. The oestradiol fraction obtained by chromatography of methylated phenolic material was divided into two halves, one of which was developed in 40 per cent sulphuric acid containing quinol for the separate colour development of oestradiol-17 $\alpha$ (to be published). The other portion of this fraction was developed for the estimation of total oestradiols. The values of oestradiol-17 $\beta$ were calculated as the difference between total oestradiols and oestradiol-17 $\alpha$.

The recovery of oestradiol-17 $\alpha$ added to intact colostrum in amounts of $5 \mu \mathrm{g}$ per $25 \mathrm{ml}$ was $48.8 \pm 12.3$ ( $\mathrm{SD}, \mathrm{n}=10$ ) per cent. The recovery of oestradiol-17 $\alpha$ when taken through the procedure for hydrolysis of conjugates amounted to $50.0 \pm 27.2(\mathrm{SD}, \mathrm{n}=8$ ) per cent. In these recovery experiments one half of the oestradiol fraction was submitted to the separate colour development of oestradiol-17 $\alpha$ in the usual way. 
Estimates of the sensitivity and precision (Brown, Bulbrook $\&$ Greenwood 1957) in determination of oestrone and oestradiol$17 \beta$ by duplicate analysis are recorded in Table 1.

\section{RESULTS}

The values obtained of free and conjugated oestrone, oestradiol-17 $\beta$ and oestradiol-17 $\alpha$ are given in Table 1. For comparison the values are also recorded of free and conjugated oestrone and oestradiol-17 $\beta$ in the milk of a non pregnant cow prior to and after parenteral administration of $50 \mathrm{mg}$ oestradiol-17 $\beta$ (Lunaas 1963).

Most of the values obtained in estimations of free oestrone and oestradiol-17 $\beta$ in colostrum were below the limit of sensitivity in the method applied. When estimating conjugated oestrone and oestradiol-17 $\beta$ the sensitivity was considerably better and most of the values, at least in colostrum from the first drawing, differed significantly from zero.

In the colostrum of one of the animals free or conjugated oestradiol-17 $\alpha$ could not be detected. Conjugated oestradiol-17 $\alpha$ was not detectable in two additional specimens from the second drawing. In the remainder of the material the values of oestradiol-17 $\alpha$ were generally much lower than those obtained for oestradiol-17 $\beta$.

\section{DISCUSSION}

The values presented of oestrogen levels in colostrum were much higher than those previously obtained in normal milk from the non pregnant cow (Lunaas 1963, cf. Table 1). However, the composition of colostrum and of normal milk may differ with respect to substances interfering with determinations of oestrogens. Although the specificity is generally assumed to be high both in the chromatographic method of Brown (1955) and in the procedure applied for Kober colour development and extraction according to Ittrich (1958), the results presented should be considered with reservations, at least until the chemical nature of the oestrogens of colostrum has been definitely established. The method applied was evidently inadequate for the determination of the colostrum levels of free oestrogens. The results were of poor reproducibility and the values were most frequently below the estimated limits of sensitivity. Moreover the apparent levels 
T a b l e 1. Oestrone $\left(\mathrm{Oe}_{1}\right)$ and oestradiols $\left(\mathrm{Oe}_{2}\right)$ in bovine colostrum.

Mean values in duplicates uncorrected for incomplete extraction and loss of substance due to the analytical procedure.

\begin{tabular}{|c|c|c|c|c|c|c|c|}
\hline \multirow{3}{*}{ Cow } & \multirow{3}{*}{ Drawing } & \multicolumn{6}{|c|}{$\mu \mathrm{g}$ per $1000 \mathrm{ml}$} \\
\hline & & \multicolumn{3}{|c|}{ Free } & \multicolumn{3}{|c|}{ Conjugated } \\
\hline & & $\mathrm{Oe}_{\mathbf{1}}$ & $O e_{2}-17 \beta$ & $0 e_{2}-17 \alpha$ & $\mathbf{O e}_{1}$ & $O e_{2}-17 \beta$ & $0 e_{2}-17 \alpha$ \\
\hline \multirow[t]{3}{*}{$\mathbf{A}$} & 1. & 5.29 & 1.51 & 0,71 & 6.07 & 5.17 & 0.39 \\
\hline & 2. & 5.95 & 6.45 & 0.14 & 2.55 & 2.38 & 0.36 \\
\hline & 3. & 6.06 & 2.72 & 0.27 & 3.29 & 1.40 & 0.11 \\
\hline \multirow[t]{3}{*}{ B } & 1. & 0.96 & 9.07 & 0.25 & 3.34 & 2.34 & 0.08 \\
\hline & 2. & 0.96 & 0.18 & 0.18 & 2.43 & 1.29 & n. d. \\
\hline & 3. & 1.00 & 0.64 & lost & 1.62 & 0.64 & lost \\
\hline \multirow[t]{2}{*}{ C } & 1. & 5.13 & 2.32 & 0.25 & 7.82 & 4.19 & 0.88 \\
\hline & 2. & 1.49 & 1.58 & 0.31 & 2.55 & 2.20 & 0.33 \\
\hline \multirow[t]{2}{*}{ D } & 1. & 3.19 & 0.52 & n. d. & 5.72 & 3.11 & n. d. \\
\hline & 2. & 1.28 & 1.99 & n. d. & 2.15 & 1.47 & n. d. \\
\hline \multirow[t]{2}{*}{$\mathbf{E}$} & 1. & 3.19 & 2.16 & 0.29 & 7.27 & 3.87 & 0.41 \\
\hline & 2. & 0.62 & 0.72 & 0.25 & 3.59 & 1.41 & n. d. \\
\hline \multicolumn{2}{|c|}{$\begin{array}{l}\text { Smallest value significantly } \\
\text { different from zero }(P=0.01)\end{array}$} & 4.57 & 4.88 & 0.41 & 1.88 & 1.77 & 0.15 \\
\hline \multicolumn{2}{|c|}{ Fiducial range $(P=0.05)$} & \pm 3.49 & \pm 3.72 & \pm 0.31 & \pm 1.43 & \pm 1.35 & \pm 0.12 \\
\hline \multicolumn{2}{|c|}{$\begin{array}{l}\text { Average values in colostrum, } \\
\text { cows A-E, first drawing }\end{array}$} & 3.55 & 3.12 & 0.30 & 6.07 & 3.74 & 0.35 \\
\hline \multicolumn{2}{|c|}{$\begin{array}{l}\text { Normal milk in } \\
\text { non pregnant cow }{ }^{\star} \text { ) }\end{array}$} & 0.04 & 0.12 & n. d. & 0.03 & 0.15 & n. d. \\
\hline \multicolumn{2}{|c|}{$\begin{array}{l}\text { After injection of } \\
50 \mathrm{mg} \text { oestradiol-17} \beta^{\star} \text { ) }\end{array}$} & 0.08 & 0.60 & n. d. & 0.38 & 7.06 & n. d. \\
\hline
\end{tabular}

n. d.: not detected

*) Lunaas (1963).

were erratic, no consistant relationship to the sequence of drawings being evident. The oestrogenic activity of free oestrogens in colostrum has previously been reported to equal $1 \mu \mathrm{g}$ oestradiol$17 \beta$ per 1 (Pope \& Roy 1953).

It appears that some confidence may be attached to the estimates of conjugated oestradiol-17 $\beta$, the average value of which in the first drawing amounted to $3.7 \mu \mathrm{g}$ per 1 . This result is in good agreement with results obtained in bioassays by Pope 
\& Roy (1953) who found that the oestrogenic activity in a non ketonic fraction of material liberated in hot acid equaled $3.4 \mu \mathrm{g}$ oestradiol-17 $\beta$ per 1 . These authors confined their studies to a sample of colostrum of the first drawing from one single cow. In the present investigation the levels of the postulated oestradiol$17 \beta$ in conjugated form in colostrum did not vary appreciably in the 5 cows examined. It was found that the levels of the second drawings were about one half (48, range: $36-55$, per cent) of those in the first. The lowest levels were found in the two specimens from the third drawing. If it is assumed that the placenta represents the most important site of oestrogen production at term, a decrease in the levels of oestrogens in colostrum with the time after parturition would be expected.

The colostrum levels of conjugated oestrone were found generally to be somewhat higher than of conjugated oestradiol17 $\beta$. The average level in the first drawing was $6.1 \mu \mathrm{g}$ per 1 which is equivalent to about $0.3 \mu \mathrm{g}$ oestradiol-17 $\beta$ in the mouse uterine weight method of assay. The biological activity of a ketonic fraction prepared from hydrolysates of colostrum extracts by Pope \& Roy (1955) was about six times as high, equaling $1.8 \mu \mathrm{g}$ oestradiol-17 $\beta$ per 1 .

In cattle oestradiol-17 $\alpha$ is an important metabolic end product of oestradiol-17 $\beta$ beside oestrone, both of which are excreted in large amounts with the urine at the time of parturition (Velle 1958). From the present investigation it would appear that the colostrum levels of free as well as of conjugated oestradiol-17 $\alpha$ are very low in comparison with the levels of oestrone and oestradiol-17 $\beta$. Estimation of conjugated oestradiol-17 $\alpha$ represents an analytical difficulty since this oestrogen is susceptible to destruction in hot acid (Velle 1958). Under the mild conditions selected for hydrolysis of colostrum oestrogen conjugates the recovery of oestradiol-17 $\alpha$ was satisfactory, but it cannot be excluded that hydrolysis of possible conjugates was incomplete. This pertains also to conjugates of oestradiol-17 $\beta$ and of oestrone. If it is assumed that the two oestradiols occur in the colostrum as conjugates hydrolysable at similar rates, the data presented indicate that the amounts of the $\alpha$-epimer eliminated via the mammary gland during and immediately after parturition are considerably smaller than those of the $\beta$-epimer. On the same assumption it seems highly improbable that the oestrogenic activity demonstrated by Pope \& Roy (1953) could have been 
due to oestradiol-17 $\alpha$, the oestrogenic potency of which, depending on the method for assay, amounts only to $1 / 40-1 / 400$ of that of oestradiol-17 $\beta$. The indication that oestradiol-17 $\beta$ may be eliminated via the mammary gland under physiological conditions is supported by the evidence previously obtained that parenteral administration of the free steroid results in increased milk levels of oestradiol-17 $\beta$ conjugates in the non pregnant cow (Lunaas 1963, cf. Table 1).

As mentioned in the introduction, the major oestrogens present in the bovine placenta are oestrone and the two oestradiols of which the $\alpha$-epimer predominates at term (Veenhuizen et al. 1960 ). The ratio in which the oestrogens are released into the maternal circulation as well as the ratio between free and conjugated oestrogens released are unknown. The major oestrogen in bovine blood obtained during the last month prior to parturition seems to be oestrone being present in conjugated form (Pope, Jones \& Waynforth 1962). The blood levels of oestradiol$17 \beta$ were apparently much lower than those of oestrone. It is interesting to note that the amounts of conjugated oestrone in the blood reported by these authors ( $6 \mu \mathrm{g}$ per 1) are virtually identical with the average contents in colostrum obtained in the present investigation. The evidence that the levels of oestradiol$17 \beta$ in comparison with the oestrone levels are higher in the colostrum than in the blood might indicate that the rates of oestrogen elimination via the mammary gland are not solely governed by the blood concentrations. Investigations on circulating oestrogens at the time of parturition would be required to substantiate this hypothesis.

The physiological significance of the colostrum oestrogens is obscure. It is possible that the amounts present in some manner merely reflects the levels of blood oestrogens to which the mammary gland has been exposed. It seems equally possible that the various oestrogens and oestrogen metabolites of blood in transfers associated with colostrum and milk secretion are segregated in the mammary gland. Finally it cannot be excluded that the lactogenic tissue is capable of transformations and conjugation of oestrogens. These questions may be relevant to the physiology of the mammary gland as a target organ of oestrogens. 


\section{ACKNOWLEDGMENTS}

Thanks are due to $S$. Tollersrud, research officer, who kindly provided the colostrum specimens, and to Miss Aud Mortensen for her skilled performance of the analyses.

The investigation was supported by grants from the Agricultural Research Council of Norway.

\section{REFERENCES}

Brown, J. B.: A chemical method for the determination of oestriol, oestrone and oestradiol in human urine. Biochem. J. 1955, 60, 185-193.

Brown, J. B., Bulbrook, R. D. \& Greenwood, F. C.: An evaluation of a chemical method for the estimation of oestriol, oestrone and oestradiol-17 $\beta$ in human urine. J. Endocr. 1957, 16, 41-48.

Ittrich, G.: Eine neue Methode zur chemischen Bestimmung der oestrogenen Hormonen im Harn. Hoppe-Seylers Z. physiol. Chem. 1958, 312, 1-14.

Lunaas, T.: A rapid method for the quantitative estimation of urinary oestrogens in the pregnant mare. Acta chem. scand. 1962, 16, 2064-2065.

Lunaas, T.: Transfer of oestradiol-17 $\beta$ to milk in cattle. Nature (London) $1963,198,288-289$.

Pope, G. S. \& Roy, J. H. B.: The oestrogenic activity of bovine colostrum. Biochem. J. 1953, 53, 427-430.

Pope, G. S., Jones, H. E. H. \& Waynforth, H. B.: Oestrogens in the blod of the pregnant cow. Biochem. J. 1962, 85, 7P.

Turner, $C$. W.: Estrogen content of colostrum and milk of dairy cattle. J. Dairy Sci. 1958, 41, 630-640.

Veenhuizen, E. L., Erb, R. E. \& Gorski, J.: Quantitative determination of free estrone, estradiol-17 $\beta$ and estradiol-17 $\alpha$ in bovine fetal cotyledons. J. Dairy Sci. 1960, 43, 270-277.

Velle, W.: Unders $\varnothing$ kelser over naturlig forekommende $\emptyset$ strogener hos drøvtyggere og gris. Thesis, 1958. Norges veterinærh øgskole, Oslo.

\section{SUMMARY}

The levels of free and conjugated oestrone, oestradiol-17 $\beta$ and oestradiol-17 $\alpha$ were estimated in bovine colostrum of the 1st, 2 nd and 3rd drawing.

The values obtained of free oestrone and oestradiol-17 $\beta$ were generally below the lowest value significantly $(P=0.01)$ different from zero $(4.5-5.0 \mu \mathrm{g}$ per 1$)$ in the method applied. The values of conjugated oestrone and oestradiol-17 $\beta$ in the first drawing exceeded the lowest value significantly different from zero $(1.5-2.0 \mu \mathrm{g}$ per I) by factors of $2-4$ and averaged 6.1 and $3.7 \mu \mathrm{g}$ per 1 respectively in the five cows examined.

The levels of conjugated oestrone and oestradiol-17 $\beta$ in the 2nd and the 3rd drawing were apparently lower than in the 1st drawing. As compared with the values obtained of free and conjugated 
oestrone and oestradiol-17 $\beta$, the corresponding values of oestradiol-17 $\alpha$ were generally much smaller, in none of the samples exceeding $1 \mu \mathrm{g}$ per 1 . In some samples oestradiol-17 $\alpha$ could not be detected.

The results are discussed in relation to previous bioassays of colostrum oestrogens.

\section{ZUSAMMENFASSUNG}

östrogene im Kolostrum von Kühen.

Quantitative Analysen von freiem und konjugiertem östron, östradiol-17 $\beta$ und östradiol-17 $\alpha$ wurden an bovinem Kolostrum von erstem, zweitem und drittem Melken nach Partus gemacht.

Die Werte freien östrons und östradiols-17 $\beta$ waren gewöhnlich niedriger als die niedrigsten Werte $(4,5-5,0 \mu \mathrm{g} / \mathrm{L})$ die signifikant von Null bei dem angewandten Verfahren abwichen. Die Werte von konjugiertem östron und östradiol-17 $\beta$ des ersten Melkens waren 2-4-mal höher als die niedrigsten verschieden von Null (1,5-2,0 $\mu \mathrm{g} / \mathrm{L}$ ) waren und betrugen durchschnittlich 6,1 bzw $3,7 \mu \mathrm{g} / \mathrm{L}$ bei den fünf Kühen, die untersucht wurden.

Die Konzentrationen konjugierten östrons und östradiols-17 $\beta$ beim zweiten und dritten Melken waren scheinbar niedriger als beim ersten Melken.

Im Vergleich zu den östron und östradiol--17ß-Werten waren die entsprechenden Werte von östradiol-17 $\propto$ gewöhnlich viel niedriger und überschritten nie $1 \mu \mathrm{g} / \mathrm{L}$. In einigen Proben war östradiol-17 $\alpha$ nicht nachweisbar.

Die Ergebnisse werden in Relation zu früheren Bestimmungen der östrogene im Kolostrum bei biologischen Metoden diskutiert.

\section{SAMMENDRAG}

Østrogener $i$ kolostrum fra ku.

Det ble foretatt kvantitativ analyse av fri og konjugert $\varnothing$ stron, $\phi$ stradiol-17 $\beta$ og $\varnothing$ stradiol-17 $\alpha$ i bovint kolostrum fra f $\varnothing$ rste, annen og tredje utmelking.

De verdier som ble funnet for fri $\varnothing$ stron og $\phi$ stradiol-17 $\beta$ lå vanligvis under den laveste verdi $(4.5-5.0 \mu \mathrm{g}$ per 1$)$ som avvek signifikant $(P=0.01)$ fra null ved den metode som ble anvendt. Verdiene av konjugert $\varnothing$ stron og $\varnothing$ stradiol-17 $\beta$ ved f $\varnothing$ rste utmelking var $2-4$ ganger h $\varnothing$ yere enn den laveste verdi signifikant forskjellig fra null (1.5-2.0 $\mu$ g per l) og utgjorde gjennomsnittlig henholdsvis 6.1 og $3.7 \mu$ g per 1 hos de fem kyr som ble unders $\phi$ kt.

Konsentrasjonene av konjugert $\varnothing$ stron og $\varnothing$ stradiol-17 $\beta$ ved annen og tredje utmelking var tilsynelatende lavere enn ved f $\varnothing$ rste utmelking.

Sammenlignet med de verdier som ble funnet for $\varnothing$ stron og $\phi$ stradiol-17 $\beta$ var de korresponderende verdier av $\phi$ stradiol-17 $\alpha$ vanligvis langt lavere og oversteg ikke $1 \mu$ g per 1 . I noen av prøvene kunne $\emptyset$ stradiol-17 $\alpha$ ikke påvises.

Resultatene diskuteres i relasjon til tidligere bestemmelser av $\phi$ strogener i kolostrum utf $\varnothing r t$ med biologiske metoder. 